\title{
Antifungal activities against oil palm pathogen Ganoderma boninense from seaweed sources
}

\author{
Syamimi Diyana Abdul Aziz , Nur Fazirah Jafarah ${ }^{a}$, Suriana Sabric, Mohd Aswad Abdul Wahab ${ }^{\mathrm{d}}$, \\ Zetty Norhana Balia Yusof ${ }^{\mathrm{a}, \mathrm{b}^{*}}$ \\ ${ }^{a}$ Department of Biochemistry, Faculty of Biotechnology and Biomolecular Sciences, Universiti Putra Malaysia, 43400 UPM, Serdang, Selangor, \\ Malaysia \\ ${ }^{b}$ Laboratory of Marine Biotechnology, Institute of Bioscience, Universiti Putra Malaysia, 43400 UPM, Serdang, Selangor, Malaysia \\ 'Department of Microbiology, Faculty of Biotechnology and Biomolecular Sciences, Universiti Putra Malaysia, 43400 UPM, Serdang, Selangor, \\ Malaysia \\ ${ }^{d D}$ epartment of Plant Protection, Faculty of Agriculture, Universiti Putra Malaysia, 43400 UPM, Serdang, Selangor, Malaysia
}

Received 9th November 2018 / Accepted 31st December 2018

\begin{abstract}
Basal stem rot (BSR) disease is the most devastating disease in oil palm which is caused by a fungal pathogen, Ganoderma boninense. However, to date, there is no reliable control for this disease. This study investigated the antifungal potential of seaweed extracts against $G$. boninense and screening of the compounds possessing this antifungal activity. Four seaweed species namely cf Sargassum oligocystum, Caulerpa racemosa, Caulerpa racemosa var. lamouroxii and ${ }_{\mathrm{cf}}$ Halimeda macrophysa were collected from Teluk Kemang, Port Dickson, Malaysia and their antifungal potential against $G$. boninense were evaluated. Two solvents with different polarities were used for crude extraction namely methanol and chloroform. Antifungal assay using crude methanolic and chloroform extracts from these seaweed species were carried out at various concentrations using the poisoned food technique. Caulerpa racemosa var. lamouroxii chloroform extract showed strong antifungal activity against $G$. boninense with $27.44 \%$ inhibition of the fungus followed by $C$. racemosa methanolic extract with $26.92 \%$ inhibition of the fungus at the lowest extract concentration of $0.25 \mathrm{mg} / \mathrm{mL}$. The extracts were subjected to Gas Chromatography-Mass Spectrometry analysis and the dominant bioactive compounds detected in both extracts were phytol and 1-(+)-ascorbic acid 2,6dihexadecanoate which were also found in plant extracts showing antimicrobial activities in previous studies. The findings suggested that local Malaysian seaweed species have high potential as a source of antifungal compounds which could be useful specifically for the application in the oil palm industry.
\end{abstract}

Keywords: antifungal activity, bioactive compounds, seaweeds, oil palm, basal stem rot, Ganoderma boninense

\section{INTRODUCTION}

Fungal infection is a serious case where it affects plants and interferes with the growth of plants mainly by utilizing the plants' nutrients. It is very severe and can even cause death to plants (Tucker and Talbot 2001). Ganoderma boninense is a soil borne pathogen which causes the basal stem rot disease in oil palm (Hushiarian et al., 2013). Neglecting the disease will affect the yield of fresh fruit bunches which will trim down the production of crude palm oil. It was estimated that in 2020, 400 thousand hectares of oil palm plantations could be affected by $G$. boninense

*Author for correspondence: Zetty Norhana Balia Yusof, Department of Biochemistry, Faculty of Biotechnology and Biomolecular Sciences, Universiti Putra Malaysia, 43400 UPM, Serdang, Selangor, Malaysia. Email zettynorhana@upm.edu.my 
(Roslan and Idris 2012). Fungal infection is not new in the oil palm industry of Malaysia. However, to date, no proper control measure is available, and this situation should be controlled urgently. Many approaches to prevent the fungal infection in oil palm have been done. The most common method is by the application of fungicide but these attempts require high cost and are not environmental friendly (Idris et al., 2002). Therefore, a more effective and sustainable remedy to this disease would be worth exploring. Research suggested that the application of thiamine activated the host defense response and suppressed plant diseases (Rapala-Kozik et al., 2012; Sylvander et al., 2013). It was proven in a study by Monaim (2011), whereby thiamine treatment makes up hydrogen peroxide generation, callose disposition, and host resistance (HR) cell death in grapevine, hence, weakening the downy mildew disease. Likewise, thiamine was also able to induce defense-related enzymes in soybean plants resulting in success control of charcoal rot disease (Abdel-Monaim, 2011). Another study demonstrated the upregulation of thiamine biosynthesis as a result of the application of endophytes which also suggest the suppression of $G$. boninense (Kamarudin et al., 2017).

On the other hand, a study by Tay and Chong (2016) on papaya leaf extract against $G$. boninense demonstrated a significant inhibition activity where at highest concentration tested (45 $\mathrm{mg} / \mathrm{mL}$ ) results in high inhibition activity. The fungicidal agent found in the extracts contained five classes of compounds: carboxylic acid, ester, fatty acid ester, phenol and steroid (Tay and Chong 2016). The potential of antimicrobial activities has also been discovered in certain seaweed extracts. Seaweeds are rich with useful bioactive substances that play important roles in biological activities such as antimicrobial (Demirel et al., 2009), antiviral (Newman et al., 2003), antiinflammation (Ranganayaki et al., 2014), anticoagulant (Chanda et al., 2010), antifouling (Maréchal et al., 2004) and antifungal activity (Ambika and Sujatha 2015; Andreea et al., 2000; Pandian et al., 2011; Saidani et al., 2012). Seaweeds are productive sources of bioactive metabolites (De Almeida et al., 2011; Hu et al., 2011). Green, brown and red algae have been known to be a rich source of biologically active metabolites with antifungal (Demirel et al., 2009), cytostatic, antiviral, antihelmintic and antibacterial activities. For example, Rajasulochana and colleagues (2013) carried out a study on the potential of marine seaweed, Kappaphycus alvarezii. From the study, it was reported that $K$. alvarezii exhibited high antifungal activity against fungus Aspergillus fumigates and showed maximum antibacterial activity against bacteria Staphylococcus aureus (Rajasulochana et al., 2013).

In this project, four common seaweeds in Malaysia namely ${ }_{\mathrm{cf}} S$. oligocystum, C. racemosa, $C$. racemosa var. lamouroxii and ${ }_{\mathrm{cf}} \mathrm{H}$. macrophysa were tested for their antifungal activity specifically against a disease-causing fungus in oil palm, $G$. boninense.

\section{MATERIALS AND METHODS}

Collection of seaweeds. Brown seaweed ${ }_{\mathrm{cf}} \mathrm{S}$. oligocystum) and green seaweeds (C. racemosa, C. racemosa var. lamouroxii and ${ }_{\mathrm{cf}} \mathrm{H}$. macrophysa) were collected from Teluk Kemang, Port Dickson, Malaysia (2॰ $26^{\prime} \mathrm{N}$ latitude; $101^{\circ} 51^{\prime} \mathrm{E}$ longitude). The collected seaweeds were washed immediately with seawater and rinsed with tap water to remove any residual salt. The seaweeds were transported to the laboratory in liquid nitrogen and identified by Prof. Phang Siew Moi from Institute of Graduate Studies, Universiti Malaya. The samples were freeze-dried using a freeze-dryer for seven days, ground into fine powder using a mechanical blender and weighed (Abirami and Kowsalya, 2012).

\section{Methanol and chloroform extract preparation.} $250 \mathrm{~mL}$ of solvent methanol and chloroform were used to extract ten grams of seaweed powder via Soxhlet extraction, respectively. The liquid extract was then cooled down and concentrated using rotary evaporator at $50-60^{\circ} \mathrm{C}$. The concentrated extracts were allowed to dry in a hot-air oven, weighed, and kept at $4{ }^{\circ} \mathrm{C}$ until further use (Abirami, 2012). The percentage yield was calculated by using the following formula:

$$
\text { Yield }(\%)=\frac{\text { Dry weight of extract }}{\text { Dry weight of plant powder }} \times 100
$$


Preparation of fungus culture. Ganoderma boninense culture was provided by Dr. Nusaibah Syed Ali from Faculty of Agriculture, Universiti Putra Malaysia. The examination of the fungus structure was done by observing under light microscope at $40 \times 10$ magnification. The growth rate of $G$. boninense culture was measured from the colony diameter of the culture daily for 14 days by using slide caliper repeated for three times in triplicates.

Antifungal assay. The antifungal activity of seaweed extracts were tested using the poisoned food technique (Bussaman et al., 2012; Schmitz 1930). One percent of dimethyl-sulfoxide (DMSO) was used as co-solvent to dissolve the seaweed extracts and were reconstituted to the concentration of $0.25,0.5$ and $1.0 \mathrm{mg} / \mathrm{mL}$. The seaweed extracts were mixed with warm potato dextrose agar (PDA) containing $100 \mu \mathrm{g} / \mathrm{mL}$ ampicillin and $100 \mu \mathrm{g} / \mathrm{mL}$ penicillin before poured in a $9 \mathrm{~cm}$ sterile petri dish. The agar was left to solidify, and a $6 \mathrm{~mm}$ agar piece of one-week old fungus mycelia was inoculated to each petri dish. The cultured plates were incubated at $27^{\circ} \mathrm{C}$ and the diameters of fungal colonies were measured daily for seven days. PDA plates treated with an equal quantity of DMSO were used as a negative control while triadimefon (SigmaAldrich, USA) was chosen as positive control due to its ability in inhibiting fungal growth (Jayaratne et al., 2001). All treatments consisted of duplicates repeated three times and the averages of the experimental results were determined. The percentage inhibition of fungal growth was obtained from the following equation:

$$
\% \text { Inhibition }=\frac{\mathrm{ADC}-\mathrm{ADT}}{\mathrm{ADC}} \times 100
$$

ADC: Average diameter of fungal culture on negative control plate

ADT: Average diameter of fungal culture on plates treated with seaweed extracts

\section{Identification of compounds via $G C-M S$} analysis. Methanol extracts were prepared by solid phase extraction (SPE) method (Abdullah et al., 2004), while the chloroform extract were subjected to syringe filtration to remove impurities. Compounds from both extracts were identified with Thermo Scientific TSQ Quantum
XLS Gas Chromatography (USA) by referring to method by Upgade and Bhaskar (2013).

Data analysis. Each treatment was replicated three times and the results were expressed as mean \pm standard deviation. The mean values were subjected to Kruskal-Wallis $\mathrm{H}$ tests (SPSS statistical package, version 22) was used to determine the significant differences $(\mathrm{p}<0.05)$ between treatments.

\section{RESULTS}

Morphological identification of seaweeds. The collected seaweeds were authenticated by Prof. Phang Siew Moi by comparing the morphology of the seaweeds from seaweeds library. Figure 1 shows the four Malaysian seaweeds collected.

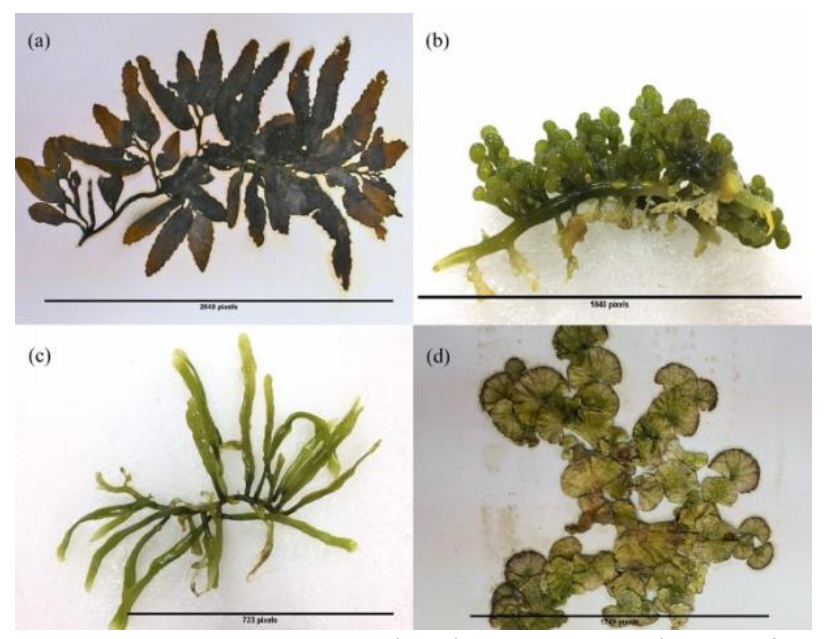

Figure 1. Four Malaysian seaweed species collected. (a) cf S. oligocystum (b) C. racemosa (c) C. racemosa var. lamouroxii (d) ${ }_{\mathrm{cf}} \mathrm{H}$. macrophysa.

Microscopic identification and growth rate of G. boninense. Figure 2 shows the identification of $G$. boninense. The formation of clamp connection (Figure 2a) is similar to identified $G$. boninense strain (Kandan et al., 2010). The shape of $G$. boninense is filamentous while the elevation view is raised. Ganoderma boninense went through lag phase starting from day one until day four followed by exponential phase on day five until day eight. At day nine and ten, the fungus undergoes stationary phase and started to die on day twelve (Figure 2b). 

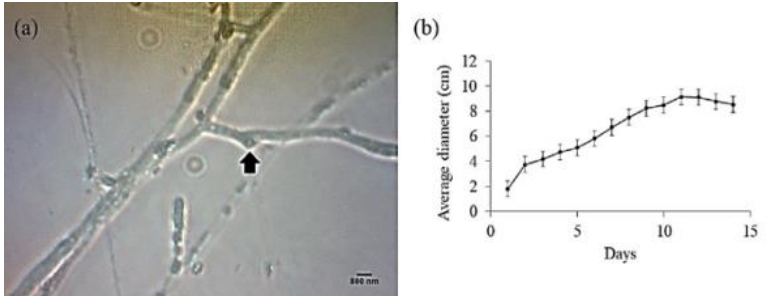

Figure 2. (a) Microscopic identification of $G$. boninense. The black arrow showing clamp connection and the morphology similar to identified $G$. boninense strain. (b) Growth rate of $G$. boninense was observed within 14 days. The growth started to deteriorate at day 12 .

Percentage yield of seaweed extracts. Two of the different extraction solvents were used per the order of their increasing polarity as different compound gets extracted in different solvents (Figure 3). From $10 \mathrm{~g}$ of seaweed powder, methanol extraction relatively produced higher yield than chloroform in all seaweed species. The extraction yield of methanol extracts ranged from $7.11 \%$ to $21.20 \%$ and chloroform extracts ranged from $1.98 \%$ to $7.11 \%$.

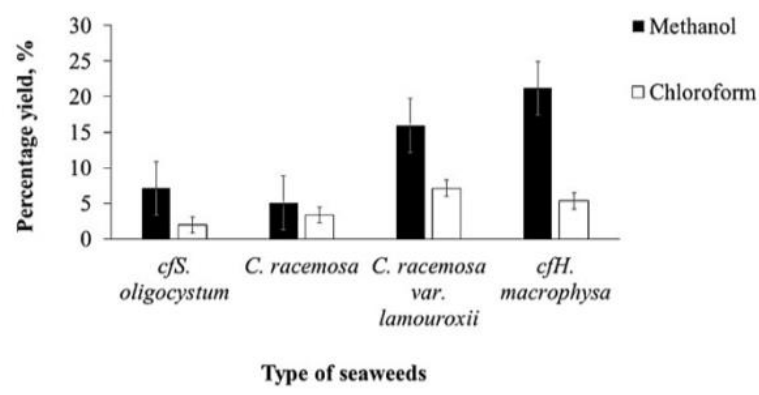

Figure 3. Percentage yield of methanolic and chloroform extracts of seaweeds. Methanolic extracts portrayed higher yield in all seaweed species compared to chloroform extracts.

\section{In vitro inhibitory effect of seaweed extracts} against $G$. boninense. The results showed that most of the seaweed extracts affect the growth of G. boninense at all three concentrations tested and comparative effectiveness of C. racemosa var. lamouroxii extract is shown in (Figure 4). The highest antifungal activities for methanolic extract against $G$. boninense at concentration of 0.25 $\mathrm{mg} / \mathrm{mL}$ were exhibited by $C$. racemosa and $C$. racemosa var. lamouroxii extracts, with inhibition percentage of $28.06 \%$ and $24.50 \%$ (Figure $4 \mathrm{a}$ ), respectively. On the other hand, the highest antifungal activities for chloroform extract against G. boninense at concentration of $0.25 \mathrm{mg} / \mathrm{mL}$ were exhibited by $C$. racemosa var. lamouroxii and ${ }_{\mathrm{cf}} \mathrm{H}$. macrophysa extracts, with inhibition percentage of $27.44 \%$ and $25.74 \%$, respectively (Figure $4 \mathrm{~b}$ ). Lower antifungal activities were detected in ${ }_{\mathrm{cf}} S$. oligocystum-chloroform extract in which the inhibition percentage was $6.82 \%$ while the methanolic extract of ${ }_{\text {cf }}$ S. oligocystum enhanced the growth of $G$. boninense.

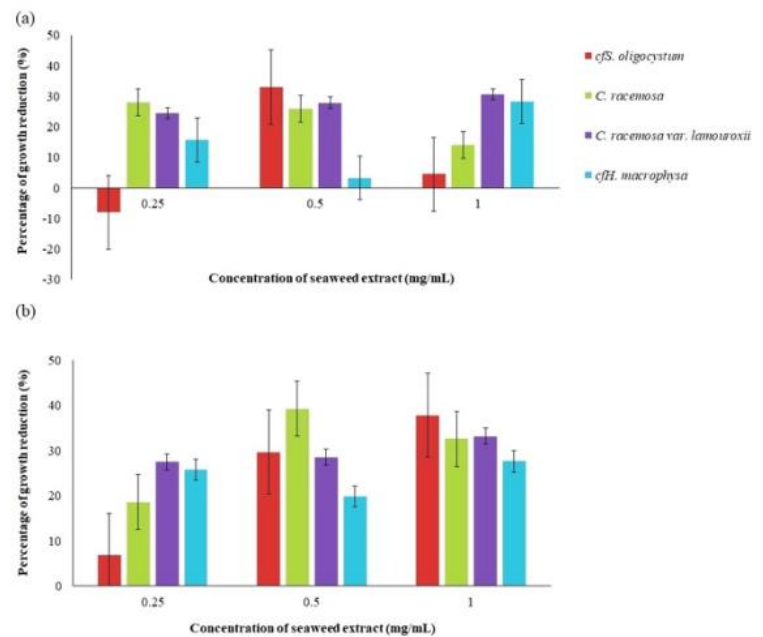

Figure 4. Susceptibility of $G$. boninense against seaweed-extracts. (a) Methanol extracts (b) chloroform extracts. Each measure represents average \pm standard deviation from three replicates per treatment.

The morphology of $G$. boninense was observed on PDA plates incorporated with methanol and chloroform extracts. In the seaweed-methanol extract plates, the mycelia growth zone was unclear, and the structure was not white and cotton-like (Figure 5a) while the culture grew in the chloroform extracts had white cotton-like mycelia, but the growth was malformed and stunted (Figure 5b).

GC-MS analysis of seaweed extracts. Compounds from seaweed extracts were identified by comparing the output of the analysis to the National Institute of Standard and Technology (NIST) database library software. For methanolic extract, a total of six major compounds were identified in ${ }_{\mathrm{cf}} S$. oligocystum extract, five major compounds in C. racemosa extract, seven major compounds in $C$. racemosa var. lamouroxii extract, and four major compounds were identified in ${ }_{g} H$. macrophysa extract (Table 1). For chloroform extracts, seven major compounds detected in ${ }_{\mathrm{cf}} \mathrm{S}$. oligocystum, $C$. racemosa var. 
lamouroxii and ${ }_{o f} H$. macrophysa extracts while five major compounds in C. racemosa extract (Table 2). Several compounds identified in methanol extracts were similar to that were found in chloroform extracts. The major classes of compounds found in all of the extracts were alkaloids, terpenes, fatty acids and sterols.

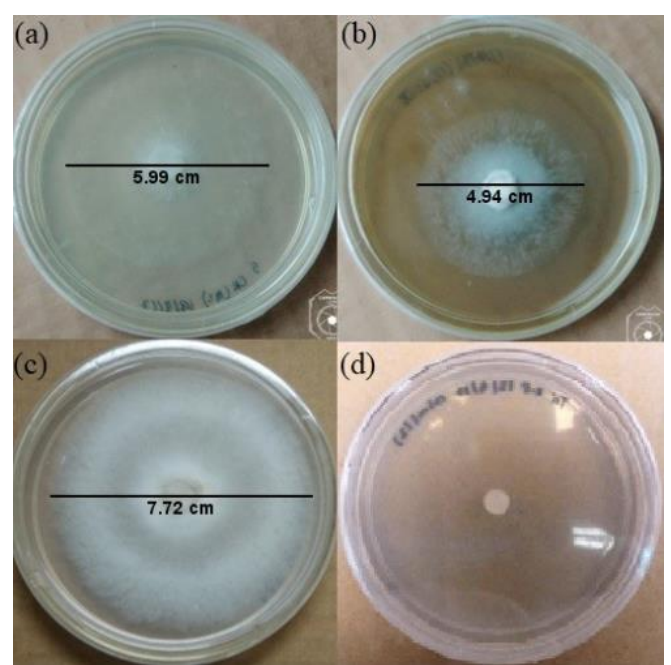

Figure 5. Growth of $G$. boninense on extractincorporated PDA after 7 days. (a) Methanolic extract of C. microphysa, (b) chloroform extract of C. racemosa, (c) negative control, (d) positive control. Red bracket: $6 \mathrm{~mm}$ fungus inoculum, black line: diameter of fungal growth.

\section{DISCUSSION}

Morphological identification of $G$. boninense was carried out by using light microscopy under $40 \mathrm{x}$ 10 magnification, and we observed clamp connection structure of $G$. boninense. The mycelia were white cotton-like whereas the mature sporophores on upper surface can be in light to dark brown color. These characteristics have been previously reported for Ganoderma species (Kandan et al., 2010). The growth of $G$. boninense was observed until day fourteen by measuring the diameter of mycelia of the fungus. During the lag phase, $G$. boninense grew through spore germination and formed mycelia which then developed primordia. Commonly, a the exponential stage, $G$. boninense produces fruiting bodies known as young sporophores and grew rapidly to mature sporophores (Kandan et al., 2010). The stationary phase was between day nine to day ten in which the growth was stunted and the shrunken of mycelia indicates its death phase at day twelve.

From this study, methanol extracts displayed better extraction capability by showing high extraction yield than chloroform extracts. This might be due to the polarity of methanol which makes it able to extract not only the polar compounds but also some non-polar compounds that is miscible to methanol such as phenolics, fatty acids, sterols, alkaloids, hydrocarbons and more (Abdel-Aal et al., 2015). Chloroform on the other hand is a non-polar solvent which can only solubilize non-polar compounds such as phenolics, diterpene alcohols, fatty acids and other non-polar compounds (Abdel-Aal et al., 2015). The major classes of compounds found in both extracts were diterpene, alkaloid, vitamin, fatty acids and steroids (Table 1).

In this study, almost all the algal extracts tested showed antifungal activity against $G$. boninense proving that extractable materials from marine algae collected from Port Dickson, Malaysia contained bioactive compounds with potential remedial interest. The broad range of classes of bioactive compounds found in seaweeds are carotenoids (Yip et al., 2014), phenolics (Airanthi et al., 2011; Matanjun et al., 2008), alkaloids (Dheeb, 2015; Pawar and Nasreen, 2016), sterols (Abdel-Aal et al., 2015), essential fatty acids (Fayaz et al., 2005; Rajasulochana et al., 2013), vitamins (Hamid et al., 2015), polyphenols, dietary fiber, polysaccharides and proteins (Ibañez et al., 2012). A KruskalWallis $\mathrm{H}$ test was conducted to know the effect of solvents and species of extracts towards growth reduction percentage of $G$. boninense. There is statistically significant difference, $r=9.6, p=.002$ in growth reduction percentage between the different solvent with a mean rank growth reduction percentage of 44.14 for solvent methanol and 28.86 for solvent chloroform. The effect of different seaweed species tested towards growth reduction percentage showed no significant difference, $\mathrm{r}=5.3, p=0.15$ with a mean rank growth reduction percentage of 40.61 for species ${ }_{\text {cf }} S$. oligocystum, 31.94 for species $C$. racemosa, 30.00 for species C. racemosa var. lamouroxii and 43.44 for species ${ }_{\mathrm{cf}} \mathrm{H}$. macrophysa. 
Table 1. Chemical constituents of seaweed-methanol extracts.

\begin{tabular}{|c|c|c|c|c|}
\hline $\begin{array}{l}\text { Type of } \\
\text { seaweed }\end{array}$ & $\begin{array}{l}\text { Retention } \\
\text { time } \\
\text { (min) }\end{array}$ & Component name & $\begin{array}{c}\text { Molecular } \\
\text { weight } \\
(\mathrm{m} / \mathrm{z})\end{array}$ & Area $(\%)$ \\
\hline \multirow{6}{*}{ cf S. oligocystum } & 8.87 & Phenol, 2,4-bis(1,1-dimethylethyl)- & 206 & 10.48 \\
\hline & 13.71 & Hexadecanoic acid, methyl ester & 270 & 3.01 \\
\hline & 14.23 & 1-(+)-Ascorbic acid 2,6-dihexadecanoate & 652 & 21.28 \\
\hline & 16.66 & cis-Vaccenic acid & 282 & 4.46 \\
\hline & 22.05 & $\begin{array}{l}\text { Hexadecanoic acid,2-hydroxy-1-(hydroxymethyl) } \\
\text { ethyl ester }\end{array}$ & 330 & 9.34 \\
\hline & 33.70 & Cholest-5-en-3-ol, 24-propylidene-, (3á)- & 426 & 4.37 \\
\hline \multirow{5}{*}{ C. racemosa } & 13.99 & 9,12,15-Octadecatrienoic acid, (Z,Z,Z)- & 278 & 19.73 \\
\hline & 14.21 & Benzenamine, 2-[2-(4-pyridinyl) ethyl]- & 198 & 11.59 \\
\hline & 16.29 & Phytol & 296 & 2.40 \\
\hline & 16.61 & 9,12-Octadecadienoic acid (Z,Z)- & 280 & 7.91 \\
\hline & 16.71 & Isobutyl methylphosphonofluoridate & 154 & 9.63 \\
\hline \multirow{7}{*}{$\begin{array}{l}\text { C. racemosa var. } \\
\text { lamouroxii }\end{array}$} & 14.19 & 1-(+)-Ascorbic acid 2,6-dihexadecanoate & 652 & 11.59 \\
\hline & 20.62 & Ethyl iso-allocholate & 436 & 3.57 \\
\hline & 21.01 & $\begin{array}{l}\text { Hexacyclo }[7 \cdot 2 \cdot 2 \cdot 2(4,7) \cdot 0(3,8) \cdot 0(12,14) \cdot 0(13,15)] \\
\text { pentadecan-1-ol-2-one }\end{array}$ & 438 & 3.16 \\
\hline & 32.70 & Benzenamine,2-[2-(4-pyridinyl)ethyl]- & 198 & 7.94 \\
\hline & 33.91 & $\begin{array}{l}\text { Spirost-8-en-11-one,3-hydroxy, } \\
\text { (3á,5á,14á,20á,22á,25R)- }\end{array}$ & 428 & 3.97 \\
\hline & 35.48 & 1-Monolinoleoylglycerol trimethylsilyl ether & 498 & 5.45 \\
\hline & 36.00 & Isobutyl methylphosphonofluoridate & 154 & 6.34 \\
\hline \multirow{4}{*}{ ofH. macrophysa } & 14.19 & 1-(+)-ascorbic acid 2,6-dihexadecanoate & 652 & 3.93 \\
\hline & 24.63 & Isobutyl methylphosphonofluoridate & 154 & 3.75 \\
\hline & 26.49 & 1-Monolinoleoylglycerol trimethylsilyl ether & 498 & 3.07 \\
\hline & 33.22 & Benzenamine,2-[2-(4-pyridinyl) ethyl]- & 198 & 4.02 \\
\hline
\end{tabular}

$\mathrm{m} / \mathrm{z}=$ mass per charge number of ions

All eight extracts were further analyzed for their compounds via GC-MS. Based on the results obtained (Tables 1 and 2), all eight extracts mainly consist of compounds from the classes of alkaloids, terpenes, fatty acids and sterols. Previous studies have shown that there are a few compounds that were identified in methanol and chloroform extracts such as phytol (Shobier et al., 2016) and 1-(+)-ascorbic acid 2,6-dihexadecanoate (Karthikeyan et al., 2014) were correlated with strong biological activities. Phytol is a precursor of vitamin $\mathrm{E}$ and vitamin $\mathrm{K}$ and was known for their antimicrobial activity (Inoue et al., 2005; Pejin et al., 2014). Phytol is widely used in the fragrance industry, cosmetics, shampoos, toilet soaps, household cleaners, and detergents (Ghaneian et al., 2015; McGinty et al., 2010). While 1-(+)-ascorbic acid 2,6-dihexadecanoate characterized from plants and marine sources was also demonstrated powerful antimicrobial activity against Staphylococcus aureus, S. faecalis, P. aeruginosa, Escherichia coli, Streptococcus pneumonia and Proteus mirabilis (Okwu and Ighodaro, 2009). Therefore, these compounds may be associated with the observed inhibitory effect on the growth of $G$. boninense in this study.

To summarize, methanol produced higher yield than chloroform due to its ability to extract polar and non-polar compounds. Three different species of marine seaweeds collected, namely, $C$. racemosa, C. racemosa var. lamouroxii and ${ }_{0} H$. macrophysa are potential species as they exhibited antifungal activities at the lowest concentration tested while ${ }_{g} \mathcal{S}$. oligocystum extract slightly inhibited the growth of $G$. boninense. Further studies to identify the antifungal compounds and their synergism should be carried out as they could be utilized as the source of antifungal compounds which could be useful to the Malaysian oil palm industry. 
Table 2. Chemical constituents of seaweed-chloroform extracts.

\begin{tabular}{|c|c|c|c|c|}
\hline $\begin{array}{l}\text { Type of } \\
\text { seaweed }\end{array}$ & $\begin{array}{l}\text { Retention } \\
\text { time } \\
\text { (min) }\end{array}$ & Component name & $\begin{array}{l}\text { Molecular } \\
\text { weight } \\
(\mathrm{m} / \mathrm{z})\end{array}$ & Area $(\%)$ \\
\hline \multirow{7}{*}{ cf S. oligocystum } & 11.72 & Tetradecanoic acid & 228 & 2.29 \\
\hline & 12.65 & Phytol & 296 & 13.02 \\
\hline & 14.28 & 1-(+)-Ascorbic acid 2,6-dihexadecanoate & 652 & 12.88 \\
\hline & 22.60 & Diisooctyl phthalate & 390 & 4.42 \\
\hline & 26.03 & Tetratriacontane & 478 & 4.98 \\
\hline & 28.26 & $\begin{array}{l}\text { 2H-1-Benzopyran-6-ol,3,4-dihydro-2,8-dimethyl- } \\
\text { 2-(4,8,12-trimethyl tridecyl)-, [2R-[2R*(4R*,8R*)]]- }\end{array}$ & 402 & 3.94 \\
\hline & 31.68 & á-Tocopherol, O-methyl- & 430 & 5.61 \\
\hline \multirow{6}{*}{ C. racemosa } & 11.75 & Tetradecanoic acid & 228 & 2.87 \\
\hline & 14.21 & 9,12,15-Octadecatrienoic acid, (Z,Z,Z)- & 278 & 17.89 \\
\hline & 14.57 & Benzenamine, 2-[2-(4-pyridinyl) ethyl]- & 198 & 32.41 \\
\hline & 16.34 & Phytol & 296 & 1.72 \\
\hline & 17.01 & Isobutyl methylphosphonofluoridate & 154 & 5.19 \\
\hline & 31.72 & á-Tocopherol, O-methyl- & 430 & 1.72 \\
\hline \multirow{7}{*}{$\begin{array}{l}\text { C. racemosa var. } \\
\text { lamouroxii }\end{array}$} & 14.19 & 1-(+)-Ascorbic acid 2,6-dihexadecanoate & 652 & 2.69 \\
\hline & 16.29 & Phytol & 296 & 6.02 \\
\hline & 17.25 & Hexadecanamide & 255 & 3.15 \\
\hline & 20.26 & Cholesta-5,7,9(11)-trien-3-ol acetate & 424 & 4.50 \\
\hline & 21.03 & Isobutyl methylphosphonofluoridate & 154 & 21.57 \\
\hline & 31.61 & (+)-ç-Tocopherol, O-methyl- & 430 & 6.80 \\
\hline & 33.50 & $\begin{array}{l}\text { Furo[3',4':6,7]naphtho[2,3-d]-1,3-dioxol-6(5aH)- } \\
\text { one,5,8,8a,9-tetrahydro-5-(3,4,5-trimethoxyphenyl) } \\
\text {-,[5R-(5à,5aá,8aà)]- }\end{array}$ & 398 & 9.51 \\
\hline \multirow{7}{*}{ H. macrophysa } & 13.49 & Benzenamine,2-[2-(4-pyridinyl)ethyl]- & 198 & 4.13 \\
\hline & 13.80 & ç-Sitosterol & 414 & 3.40 \\
\hline & 13.96 & Isobutyl methylphosphonofluoridate & 154 & 6.51 \\
\hline & 14.27 & 1-(+)-Ascorbic acid 2,6-dihexadecanoate & 652 & 13.41 \\
\hline & 16.30 & Phytol & 296 & 4.55 \\
\hline & 20.69 & 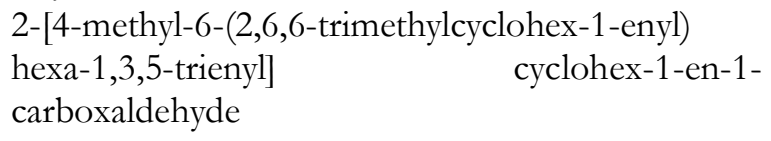 & 324 & 4.11 \\
\hline & 31.45 & Cholesterol & 386 & 4.84 \\
\hline
\end{tabular}

$\mathrm{m} / \mathrm{z}=$ mass per charge number of ions

\section{ACKNOWLEDGEMENTS}

The authors gratefully acknowledge Prof. Phang Siew Moi from Institute of Graduate Studies, Universiti Malaya for the authentication of seaweed species used in this research and Dr. Nusaibah Syed Ali from Fakulti Pertanian, UPM for providing the fungal materials. This research was funded by Geran Putra IPS Universiti Putra Malaysia (Project No. 9511100), Higher Institution Centre of Excellence (HICOE) Research Grant (Innovative Vaccines and Therapeutics against Fish Diseases) (Project No.
6369100), and SATREPS (JICA-JST): COSMOSMOHE G4-B Research Grant (Microalgae for Sustainable Aquaculture Health: Microalgae Vaccine Delivery System) (Project No. 6300866).

\section{REFERENCES}

Abdel-Monaim, M. F. 2011. Role of riboflavin and thiamine in induced resistance against charcoal rot disease of soybean. African Journal of Biotechnology 10: 10842-10855.

Abdel-Aal, E. I., Haroon, A. M., \& Mofeed, J. 2015. Successive solvent extraction and GC-MS analysis for the evaluation of the phytochemical constituents of the filamentous green 
alga Spirogyra longata. Egyptian Journal of Aquatic Research 41: 233-246.

Abdullah, S., Gobilik, J., \& Phin Chong, K. 2014. In vitro antimicrobial mode of action of Cynodon dactylon (L.) Pers. solid phase extract(SPE) against selected pathogens. Development in Sustainable Chemical and Bioprocess Technology. Publ. Springer US: 227-237.

Airanthi, M. K. W.-A., Hosokawa, M., \& Miyashita, K. 2011. Comparative antioxidant activity of edible Japanese brown seaweeds. Journal of Food Science 76: C104-C111.

Ambika, S. \& Sujatha, K. 2015. Antifungal activity of aqueous and ethanol extracts of seaweeds against sugarcane red rot pathogen (Colletotrichum falcatum). Scientific Research and Essays 10: 232-235.

Andreea, C., Oana, A., \& Beatrice, I. 2000. Antifungal activity of macroalgae extracts. UASVM Bucharest, Series A LIII: 442447.

Bussaman, P., Namsena, P., Rattanasena, P., \& Chandrapatya, A. 2012. Effect of crude leaf extracts on Colletotrichum gloeosporioides (Penz.) Sacc. Psyche (New York) 2012.

Chanda, S., Dave, R., Kaneria, M., \& Nagani, K. 2010. Seaweeds: A novel, untapped source of drugs from sea to combat infectious diseases. Current Research, Technology and Education Topics in Applied Microbiology and Microbial Tecbnology 473-480.

De Almeida, C. L. F., Falcão, H. D. S., Lima, G. R. D. M., Montenegro, C. D. a, Lira, N. S., de Athayde-Filho, P. F., Rodrigues, L. C., de Souza, M. F. V, Barbosa-Filho, J. M., \& Batista, L. M. 2011. Bioactivities from marine algae of the genus Gracilaria. International Journal of Molecular Sciences 12: 4550-4573.

Demirel, Z., Yilmaz-koz, F., Karabay-Yavasoglu, U. N., Ozdemir, G., \& Sukatar, A. 2009. Antimicrobial and antioxidant activity of brown algae from the Aegean Sea. Journal of Serbian Chemical Society 74: 619-628.

Dheeb, B. I. 2015. Antifungal activity of alkaloids and phenols compounds extracted from black pepper Piper nigrum against some pathogenic fungi. Journal of Biotechnology Research Centre 9: 46-54.

Fayaz, M., Namitha, K. K. N., Murthy, K. N. C., Swamy, M. M., Sarada, R., Khanam, S., Subbarao, P. V, \& Ravishankar, G. A. 2005. Chemical composition, iron bioavailability, and antioxidant activity of Kappaphycus alvarezzi (Doty). Journal of Agricultural and Food Chemistry 53: 792-7.

Ghaneian, M. T., Ehrampoush, M. H., Jebali, A., Hekmatimoghaddam, S., \& Mahmoudi, M. 2015. Antimicrobial activity, toxicity and stability of phytol as a novel surface disinfectant. Environmental Health Engineering and Management Journal 2: 13-16.

Hamid, N., Ma, Q., Boulom, S., Liu, T., Zheng, Z., Balbas, J., \& Robertson, J. 2015. Chapter 8 - Seaweed minor constituents. Seaweed Sustainability: 193-242.

Hu, J., Yang, B., Lin, X., Zhou, X. F., Yang, X. W., \& Liu, Y. 2011. Bioactive metabolites from seaweeds. Handbook of Marine Macroalgae: Biotechnology and Applied Phycology: 262-284.

Hushiarian, R., Yusof, N. A., \& Dutse, S. W. 2015. Detection and control of Ganoderma boninense: strategies and perspectives. Springerplus 2: 555.

Ibañez, E., Herrero, M., Mendiola, J. A., \& Castro-Puyana, M. 2012. Extraction and characterization of bioactive compounds with health benefits from marine resources: macro and micro algae, cyanobacteria, and invertebrates. Marine Bioactive Compounds. Springer US, Boston, MA: 55-98.

Idris, A., Ismail, S., \& Arifin, H. 2002. Control of Ganodermainfected palm-development of pressure injection and field applications. MPOB Information Series.

Inoue, Y., Hada, T., Shiraishi, A., Hirose, K., Hamashima, H., \& Kobayashi, S. 2005. Biphasic effects of geranylgeraniol, teprenone, and phytol on the growth of Staphylococcus aureus. Antimicrobial. Agents and Chemotherapy 49: 1770-1774.

Jayaratne, R., Wettasinghe, P. C., Siriwardene, D., \& Peiris, P. 2001. Systemic fungicides as a drench application to control white root disease of rubber. Journal Rubber Research Institute of Sri Lanka 84: 1-17.

Kamarudin, A. N., Lai, K. S., Lamasudin, D. U., Idris, A. S., \& Balia Yusof, Z. N. 2017. Enhancement of thiamine biosynthesis in oil palm seedlings by colonization of endophytic fungus Hendersonia toruloidea. Frontier in Plant Science 8: 1799.

Kandan, A., Bhaskaran, R., \& Samiyappan, R. 2010. Ganoderma-a basal stem rot disease of coconut palm in south Asia and Asia pacific regions. Archives of Phytopathology And Plant Protection 43: 1445-1449.

Karthikeyan, S. C., Velmurugan, S., Donio, M. B. S., Michaelbabu, M., \& Citarasu, T. 2014. Studies on the antimicrobial potential and structural characterization of fatty acids extracted from Sydney rock oyster Saccostrea glomerata. Annals of Clinical Microbiology and Antimicrobials 13: 332.

Maréchal, J.P., Culioli, G., Hellio, C., Thomas-Guyon, H., Callow, M.E., Clare, A.S. and Ortalo-Magné, A. 2004. Seasonal variation in antifouling activity of crude extracts of the brown alga Bifurcaria bifurcata (Cystoseiraceae) against cyprids of Balanus amphitrite and the marine bacteria Cobetia marina and Pseudoalteromonas haloplanktis. Journal of Experimental Marine Biology and Ecology 313: 47-62.

Matanjun, P., Mohamed, S., Mustapha, N. M., Muhammad, K., \& Ming, C. H. 2008. Antioxidant activities and phenolics content of eight species of seaweeds from north Borneo. Journal of Applied Phycology 20: 367-373.

McGinty, D., Letizia, C. S., \& Api, A. M. 2010. Fragrance material review on phytol. Food and Chemical Toxicology 48: S59-S63.

Newman, D., Cragg, G., \& Snader, K. 2003. Natural products as sources of new drugs over the period 1981-2002. Journal of Natural Products 66: 1022-1037.

Okwu, D. E. \& Ighodaro, B. U. 2009. GC-MS evaluation of the bioactive compounds and antibacterial activity of the oil fraction from the stem barks of Dacryodes Edulis G. Don Lam. International Journal of Drug Development and Research: 117.

Pandian, P., Selvamuthukumar, S., \& Manavalan, R. 2011. Screening of antibacterial and antifungal activities of red marine algae Acanthaphora spicifera (Rhodophyceae). Journal of Biomedical Scientific Research 3: 444-448.

Pawar, D. S. \& Nasreen, S. 2016. Phytochemical screening and antifungal activity of Baubinia racemosa and Dolichandrone falcata. International Journal of Applied Research 2: 243-245.

Pejin, B., Savic, A., Sokovic, M., Glamoclija, J., Ciric, A., Nikolic, M., Radotic, K., \& Mojovic, M. 2014. Further in vitro evaluation of antiradical and antimicrobial activities of phytol. Natural Product Research 28: 372-376.

Rajasulochana, P., Krishnamoorthy, P., \& Dhamotharan, R. 2013. An investigation on the antioxidants, antifungal and antibacterial of the Kappaphycus Alvareziii. Research Journal of Pharmaceutical, Biological and Chemical Sciences 4: 586-594.

Ranganayaki, P., Susmitha, S., \& Vijayaraghavan, R. 2014. Study on metabolic compounds of Kappaphycus alvarezii and its in-vitro analysis of anti-inflammatory activity. International Journal of Current Research and Academic Review 2: 157-166.

Rapala-Kozik, M., Wolak, N., Kujda, M., \& Banas, A.K. 2012. The upregulation of thiamine (vitamin B1) biosynthesis in Arabidopsis thaliana seedlings under salt and osmotic stress conditions is mediated by abscisic acid at the early stages of this stress response. BMC Plant Biology 12: 2.

Roslan, A. \& Idris, A.S. 2012. Economic impact of Ganoderma incidence on Malaysian oil palm plantation - A case study in Johor. Oil Palm Industry Economic Journal 12: 24-30. 
Saidani, K., Bedjou, F., Benabdesselam, F., \& Touati, N. 2012. Antifungal activity of methanolic extracts of four Algerian marine algae species. African Journal of Biotechnology 11: 94969500 .

Schmitz, H. 1930. Poisoned food technique. Industrial and Engineering Chemistry Ed. 2: 361-363.

Shobier, A. H., Abdel Ghani, S. A., \& Barakat, K. M. 2016. GC/MS spectroscopic approach and antifungal potential of bioactive extracts produced by marine macroalgae. Egypt. Journal of Aquatic Research 42: 289-299.

Sylvander, P., Häubner, N., \& Snoeijs, P. 2013. The thiamine content of Phytoplankton cells is affected by abiotic stress and growth rate. Microbial Ecology 65: 566-577.
Tay, Z. H. \& Chong, K. P. 2016. The potential of papaya leaf extract in controlling Ganoderma boninense. IOP Conference Series: Earth and Environmental Sciences 36: 1-7.

Tucker, S. L. \& Talbot, N. J. 2001. Surface attachment and prepenetration stage development by plant pathogenic fungi. Annual Review of Phytopathology 39: 385-417.

Yip, W. H., Joe, L. S., Mustapha, W. A. W., Maskat, M. Y., \& Said, M. 2014. Characterisation and stability of pigments extracted from Sargassum binderi obtained from Semporna, Sabah. Sains Malaysiana 43: 1345-1354. 